\title{
Thomas Aquinas and Hervaeus Natalis on First and Second Intentionality
}

\author{
Fabrizio Amerini ${ }^{1}$ (D) \\ Accepted: 4 May 2021 / Published online: 7 June 2021 \\ (c) The Author(s) 2021
}

\begin{abstract}
Thomas Aquinas and Hervaeus Natalis $(\dagger 1323)$ share a correlational theory of intentionality. When I cognize a thing, I am in a real relation with the thing cognized and at the same time the thing is in a relation of reason with me. Hervaeus coins the term "intentionality" to designate precisely this relation of reason. First and second intentionality express two stages of this relation. First intentionality refers to the relation that a thing has to the mind, while second intentionality indicates the relation that a thing qua cognized has to the mind. Thus, first intentionality involves direct cognition, while second intentionality reflexive cognition. This theory of intentionality has two purposes: first, to de-psychologize the cognitive process and second, to allow the application of Aristotle's table of categories to the sphere of the mental. Through his detailed analysis of the relation of intentionality, Hervaeus clarifies some of Thomas's obscurer points, but at the same time he has to solve a delicate problem of circularity entailed by the notion of intentionality as a relation of reason.
\end{abstract}

Keywords Thomas Aquinas $\cdot$ Hervaeus Natalis $\cdot$ Intentionality $\cdot$ Mental being $\cdot$ Theory of relation

\section{Introduction}

In this article, I reconsider two significant medieval treatments of first and second intentionality, namely those of Thomas Aquinas and Hervaeus Natalis, the Master General of the Dominican Order between 1318 and 1323. Hervaeus updates Thomas's theory of intentionality after Duns Scotus's intervention and becomes the most important representative of what Laurent Cesalli aptly called "correlational theories of intentionality".

Their correlational theory of intentionality results from the application of Aristotle's theory of categories to the case of intellective knowledge. This model prescribes (i) that every action entail a relation, (ii) that every relation be the outcome of the conjunction of two opposite relations, and (iii) that every relation presuppose a non-relational accident on which it is said to be founded. ${ }^{2}$ The reason for claim (ii), in particular, is that every relation metaphysically reduces to an accident of the relational kind. Since every accident

Fabrizio Amerini

fabrizio.amerini@unipr.it

1 Department of Humanities, Social Science and Cultural Industries (DUSIC), University of Parma, Via M. d'Azeglio 85 - I-43100, Parma, Italy can inhere only in one subject, while a relation is an accident that connects two subjects to each other, this entails that a second relation, inhering in the other subject, is needed. Apparently, the case of cognition could be an exception, since cognition expresses, as Aristotle teaches in Metaphysics $\mathrm{V}$, c. 15, a one-sided relation. Aristotle explains that cognition is an asymmetrical relation because, when I cognize an extramental thing, the thing is not cognizing me; moreover, an extramental thing is called "cognized" not because it develops some relation to me, but only because I develop a relation to it. Thomas and Hervaeus, however, endeavour to maintain claim (ii) also in the case of cognition. On their interpretation of Aristotle, the one-sided nature of the relation of cognition does not mean that the cognized thing develops no relation with my mind, but only that the two opposite relations entailed by my act of cognition are not of the same kind. Thomas and Hervaeus hold that the relation

\footnotetext{
${ }^{1}$ Cesalli (2010). On Scotus's criticism of Aquinas, see Pini (2002, pp. 99 ff., esp. pp. 120-125); also Pini (2005). On the distinction between first and second intentionality, its history and significance see Perler (2002) and De Rijk (2005).

${ }^{2}$ For an introduction to the medieval theories of relation, see Henninger (1989). In this article I limit myself to the case of the intellective knowledge of extramental things. Although medievals use different terms for speaking of this kind of knowledge, I do not distinguish them; for the sake of brevity, I refer to it by the term 'cognition'.
} 
that goes from my mind to the thing is a real relation, while the relation that goes from the thing to my mind is a relation of reason.

Hervaeus is the first to use the abstract term "intentionality" in philosophical jargon, although by this term he means exactly the opposite of what we mean today: "intentionality" is coined to designate precisely the converse-relation of the relation of cognition, namely the relation of cognition as passively understood (i.e., the relation of being cognized). ${ }^{3}$ In this model, the distinction between first and second intentionality tries to capture the twofold movement that naturally characterizes the human mind. We first turn to extramental things, then to ourselves and to the cognized things. From the point of view of the cognized thing, first intentionality indicates the relation that an extramental thing has to our mind, while second intentionality indicates the relation of a cognized thing to our mind. If not Thomas and Hervaeus directly, it is this correlational conception of intentionality that Brentano seems to have in mind when he refers to the Scholastic heritage. ${ }^{4}$

This correlational account is justified, first of all, by technical reasons connected to medieval theories of relation. But there it also has some theoretical grounds. The most important is the need to make a sharp distinction between what happens on the side of the cognizing mind and what happens on the side of the thing cognized. When I am performing an act of intellective cognition of a man, for example, my act of cognition and the cognized man amount to two different things; a proof is that they are subjects of different predications. In fact, man is said to be cognized by me, while I am said to be cognizing a man. The relation I bear to man allows the latter predication, while the relation man has to my mind allows the former. Being cognizing and being cognized concern different subjects and, what is more, say properties of the relational kind. Of course, my act of cognition is a necessary condition for the converse-relation of being cognized to hold, but such a relation is not directly founded on my act. As we shall see, Thomas and Hervaeus hold that it is founded on the cognized thing, for it expresses the actualization of the extramental thing's intrinsic property of being naturally predisposed to be cognized by us. The distinction between the subject-cognizer side and the thing-cognized side of intentionality can be helpful for two purposes: first, to de-psychologize the cognitive process and accordingly keep distinct, in an act of cognition, what comes from the world from what is supplied by the mind; and second, to

\footnotetext{
${ }^{3}$ See, e.g., $D S I$, d. 1, q. 2 (ed. Dijs 2012, p. 133, n. 61): "[...] intentionalitas qua prima intentio dicitur 'intentio', super rem quae intelligitur non addit nisi ipsam esse obiective in intellectu. Hoc autem est ipsam habere relationem ad actum intelligendi."

${ }^{4}$ For more on this, see Taieb (2018a).
}

allow the application of Aristotle's table of categories to what happens in the mental.

The plan of the article is the following. I reconstruct Thomas's view of first and second intentionality in Sect. 2 . Then, in Sect. 3, I examine Hervaeus's discussion of the notion of intentionality understood as the converse-relation of the relation of cognition. Hervaeus clarifies some obscurities of Thomas's account, but in turn he has to solve a delicate problem of circularity.

\section{Thomas Aquinas}

Thomas is well acquainted with the distinction between first and second intentionality. ${ }^{5}$ Often however, he simply calls "intentions" concepts of properties of the intentional kind, such as "being universal" or "being a species," and contrasts them to concepts of things, which he calls "conceptions". Let me begin the discussion of Thomas's view of first and second intentionality with a text from his Quaestiones de potentia, a work that dates from the years $1265-1266 .{ }^{6}$

\subsection{Thomas Aquinas's Account of First and Second Intentionality}

In question 7, article 9, Thomas divides things into two classes. He says that there are things that are cognized in the first instance, and these are the extramental things; and there are things that are cognized in the second instance, and these are the intentions:

The things first understood are outside the soul, and intellect bears on them as things to be understood; what is thought secondly are called intentions consequent on our mode of understanding, and these the intellect understands secondly insofar as it reflects on itself, understanding itself to understand and the manner in which it understands. ${ }^{7}$

\footnotetext{
5 The distinction recurs, for example, in In I Sent., d. 23, q. 1, a. 3, co (ed. Mandonnet 1929, p. 563); d. 26, q. 2, a. 1, co (ed. Mandonnet 1929, p. 630); In III Sent., d. 5, q. 3, a. 1, ad 1 (ed. Moos 1933, p. 205). All references to In I Sent. are from Thomas Aquinas (1929), while references to In III Sent. are from Thomas Aquinas (1933). For details of Aquinas's view of intentionality, see Schmidt (1966); Solère (1989); Kenny (1993); Stump (1998); Black (1999); Pini (2002); De Rijk (2005); Brower and Brower-Toland (2008); Galluzzo (2010); Amerini (2013); Klima (2017). I refer to these studies for further literature.

${ }^{6}$ For the chronology of Aquinas's works, see Porro (2016).

7 De pot., q. 7, a. 9, co (ed. Pession 1965, pp. 63-64): "Prima enim intellecta sunt res extra animam, in quae primo intellectus intelligenda fertur. Secunda autem intellecta dicuntur intentiones consequentes modum intelligendi: hoc enim secundo intellectus intelligit in quantum reflectitur supra se ipsum, intelligens se intelligere et
} 
In this text, Thomas connects the first/second intentionality divide to the distinction between direct and reflexive cognition. However, not all is clear with this connection. A first point of non-clarity concerns the domain of the things that are firstly and secondly cognized. Thomas says that extramental things are firstly cognized, and they can be called firstly cognized because our mind bears on them first. Since Thomas does not admit acts of intellective intuition of extramental things that can lead to the formation of individual concepts, we are said to cognize intellectively a thing only when we reach a universal conception of it. As Thomas characterizes it in Quaestiones de potentia, q. 8, a. 1 , the conception of a thing is nothing other than the "termination" of the act of cognition of that thing. It does not matter here whether the conception has to be understood in a realistic or in a mentalistic way, that is, as the extramental thing's nature itself with a sui generis mode of existence in the mind or rather as a mental representation of it. What is important to retain here is that the process of cognition that Thomas has in mind includes a sort of leap. Our mind begins its cognition from an extramental singular thing (say Socrates) and ends at a different thing, viz., the conception (for example man), so that the thing to which we are initially turned does not coincide with what we finally know about that thing. I cognize Socrates only when I know that Socrates is a man. My intellective access to the extramental world is, thus, always mediated by a conception (in the case of Socrates, by that of man), which is the true object of my cognition and that with which I am actually in relation. As Thomas writes in his Sentences Commentary, when I am turned to an extramental thing, I cognitively relate to the conception of the thing firstly and only through the conception we can relate to the extramental thing itself. ${ }^{8}$

But when we consider the things secondly cognized, this scheme no longer holds. In this case, there is an inversion, because the things secondly cognized are the intentions. We find here, too, the same leap as in the case of first intentionality, for our mind starts from a universal conception (e.g.,

\section{Footnote 7 (continued)}

modum quo intelligit." Transl. McInerny (1998, p. 330). All references to De pot. are from Thomas Aquinas (1965).

${ }^{8}$ See In I Sent., d. 35, q. 1, a. 2, co (ed. Mandonnet 1929, pp. 814815): “[...] intellectum primum est ipsa rei similitudo, quae est in intellectu; et est intellectum secundum ipsa res, quae per similitudinem illam intelligitur." Here Thomas says that the conception is the thing cognized in the first instance, while the extramental thing is the thing cognized in the second instance. This text could not conflict, however, with what Thomas says in Quaestiones de potentia because in that place of the Sentences Commentary he is describing the process of recognition of a thing and not that of the genesis of cognition. An extramental thing is the first thing we attempt to know, but a conception is what we first know about an extramental thing. For further discussion, see Cory (2020). man) and ends at an intention (e.g., species). Here, however, the things secondly cognized are not the things to which we are secondly turned, i.e. the conceptions, as one would expect it to be, but the intentions. We shall see better later how such intentions are generated; for the time being, we may note that acts of second intentionality are those that lead to the formation of a specific class of properties that we can attach to the conceptions of things. In our example, being a species is an intentional property that can be attributed to man and this happens only when our mind bears on man. In the Quaestiones de potentia, though, this apparent inversion is not explained further by Thomas. Nevertheless, the inversion is understandable: intentions may be said to be the things secondly cognized in that they are what we secondly know about extramental things.

There is also a second point of non-clarity in the text above, which concerns the mechanisms underlying the formation of intentions. Thomas says that secondly cognized things result from an act of reflection of our mind upon itself. By this act, our mind is said to know both the fact that it is cognizing and the manner in which it is cognizing (viz., the things firstly cognized). In our example, if I am cognizing Socrates, I am performing an act of first intentionality. But if I am reflecting on myself and on the manner in which I am cognizing Socrates, I am performing an act of second intentionality. Now, the process of self-reflection of our mind involves a complexity, which Thomas does not illustrate. The "manner in which" mentioned in the text above undoubtedly refers to my mind's mode of cognizing a thing that has been firstly cognized (for example, the mode of cognizing universally Socrates, through the conception of man). So, the object of my act of reflection on myself appears to be, in the first instance, a fact that concerns my mind itself and its mode of cognizing. This logically entails that, if intentions are supposed to ensue from an act of reflection, they should be attributed to the cognizing mind in the first instance and not to the cognized thing. This is not, however, what Thomas says. For Thomas, intentions are properties of the cognized thing, and not properties of the cognizing mind. In fact, I am performing an act of second intentionality not when I know that I am cognizing Socrates, but when I know that what has been cognized of Socrates, for example the conception of man, is universal or a species. However, through an act of reflection, my mind reflects on the cognized thing only in the second instance. In the Quaestiones de potentia, however, this shift from reflecting on the cognizing mind to reflecting on the cognized thing is not explained by Thomas.

\subsection{Second Intentionality, Reflexivity, and Relationship of Reason}

In order to clarify these opacities, we should look at what Thomas says in his Commentary on the Metaphysics, a work 
which dates from a later stage of his career (after 1270). Commenting on Book IV, Thomas makes an important observation:

There are two kinds of beings: beings of reason and real beings. The expression "being of reason" is applied properly to those notions which reason derives from the objects it considers, for example, the notions of genus, species and the like, which are not found in reality but are a natural result of the consideration of reason. ${ }^{9}$

The mind's act of reflection of which Thomas spoke in the Questiones de potentia is specified, in the text above, as an act of consideration. When I am reflecting on myself while cognizing Socrates, I not only know the fact that I am cognizing Socrates and the manner in which I am cognizing him, but I can also consider Socrates involved in my act of cognizing. Through this act of consideration, Thomas says, I can "discover" the intentions. He adds that such intentions cannot be found in external reality, but simply "follow" my act of consideration. Although not all the points of Thomas's picture are yet clear, one point is certain: through an act of reflection I can be conscious of myself cognizing Socrates as well as I can consider the conceptions I obtained about Socrates, and in this second case, I can "discover" the intentions.

The Commentary on the Metaphysics could lead someone to think that the act of consideration of a thing that has been firstly cognized is, for Thomas, a sufficient condition for forming the intentions. But it is not so. Thomas seems to hold that nothing in the thing that we are considering can direct our intellect toward one or another intention. True, he says that our mind "discovers" (adinvenit) the intentions, but I think one should not take him to mean that our mind finds the intentions inside the thing under consideration, but that our mind forms the intentions only in consequence of its act of consideration of the cognized thing. As Thomas will make clear in another Aristotelian commentary contemporary to that on the Metaphysics, namely the Commentary on the De interpretatione, the formation of intentions also requires an act of comparison. Thus, to form the intention of species it does not suffice to consider the conception of man, but it is necessary to compare it with the extramental

\footnotetext{
9 Exp. Met., IV, lec. 4 (ed. Spiazzi 1964, n. 574): "Et hoc ideo est, quia ens est duplex: ens scilicet rationis et ens naturae. Ens autem rationis dicitur proprie de illis intentionibus, quas ratio adinvenit in rebus consideratis, sicut intentio generis, speciei et similium, quae quidem non inveniuntur in rerum natura, sed considerationem rationis consequuntur." Transl. Rowan (1961, p. 199). All references to Exp. Met. are from Thomas Aquinas (1964).
}

things from which it has been abstracted. ${ }^{10}$ When I compare man with Socrates and Plato, I "discover" that it can be predicated of both and so I can form the intention of species. In fact, by species, we mean precisely this feature of man, namely being predicable of many extramental things that differ in number. Thomas is unequivocal in claiming that, when our mind reflects on itself, it moves to considering and comparing the cognized things and, in doing so, it attaches intentions not to itself but to the cognized things:

Sometimes we attribute something to it [i.e., to the universal considered in this way, i.e., as separated from singulars] that pertains only to the operation of the intellect; for example, as when we say that man is [something] predicable of many things, or universal, a genus or a species. For the intellect forms intentions of this kind, attributing them to the nature understood as comparing itself to the things outside of the mind. ${ }^{11}$

In this text, Thomas mentions such intentions as being predicable, being universal, being a genus or a species, and says that they all result from an act of comparison of a cognized thing's nature (or a conception; it amounts to the same) with extramental things. In other texts, like Quaestiones de potentia, q. 7, a. 11, Thomas broadens the perspective and says that the formation of intentions is also made possible thanks to the mind's act of comparison of two cognized things' natures with each other. ${ }^{12}$

With respect to the mechanisms of formation of intentions we have reconstructed so far, we may note three things.

(1) First, in his works, Thomas does not explain whether my act of reflecting on myself coincides with my act of considering the cognized thing and if this latter act, in turn, coincides with that of comparing the thing cognized to extramental things or to another cognized thing. One may reasonably argue that considering and comparing amount to two distinct mental operations: in fact, it is not difficult

\footnotetext{
${ }^{10}$ Given Thomas's universalist account of intellective knowledge, this comparison with extramental things could be difficult to understand. Thomas does not clarify the details of it, but one can suppose that it happens through the mediation of the sensory process, i.e. through the conversion to the phantasms of imagination as Thomas tells it.

11 Exp. Per., I 10 (Leon. 1*/1, p. 51, 11. 130-150): "Quandoque enim attribuitur ei sic considerato aliquid quod pertinet ad solam actionem intellectus, ut si dicatur quod homo est predicabile de multis aut uniuersale aut genus aut species; huiusmodi enim intentiones format intellectus attribuens eas nature intellecte, secundum quod comparat ipsam ad res que sunt extra animam." Transl. Oesterle (1962, p. 80); slightly modified. All references to ed. Leon. are from Thomas Aquinas (1882-).

12 See, e.g., De pot., q. 7, a. 11, co (ed. Pession 1965, p. 212): “[...] has enim relationes ratio adinvenit considerando ordinem eius quod est in intellectu ad res quae sunt extra, vel etiam ordinem intellectuum ad invicem."
} 
to imagine that I can consider a thing in itself without comparing it to anything else. But the relation between the act of reflection and that of consideration is more uncertain. On the one hand, since, in Thomas's theory of knowledge, it is not possible to give the case that we cognize and that we do not cognize anything, it follows that, when I reflect on myself and know that I am cognizing, I also know that I am cognizing a thing. But on the other hand, it remains uncertain if this act of reflection also coincides with the act of considering the cognized thing. One may suppose that the two acts do not coincide, because when I reflect on myself, I first consider myself cognizing, and only afterwards do I move to consider the thing that I am cognizing on its own. Two distinct and consecutive acts of consideration could be thus involved in my act of reflection, and they could explain the shift from me as cognizing to the thing as cognized. ${ }^{13}$

(2) A second thing to be noted is that the comparison of a cognized thing to extramental things or to another cognized thing gives rise to what Thomas calls a "relation of reason". In medieval theories of relation, this technical notion is used to indicate a relation that has no real counterpart in the outer world but that only arises in consequence of an act of reason. ${ }^{14}$ For my argument, it is important to underscore only one implication of this conception, namely that intentions are seen as properties that are relational in character. Consider the case of species and genus. If I compare a genus such as animal to a species such as man, I "discover" that animal is predicable of man and I can also "discover" that it is predicable of the other animal-species as well. Thus, I reach the Porphyrian concept of genus: I define indeed animal as a genus when I state that animal is that which can be predicated of many things that are different in species. My different acts of comparison can generate different relations of reason, which I express in terms of the different predications they give rise to. I define the genus in terms of its being predicable of the species and vice versa, so the property of being a genus states a relational property: it says how a cognized thing, such as animal, predicatively behaves with respect to another cognized thing, such as man. As it seems, even the intentions resulting from the acts of comparison of cognized things to extramental things, such as being universal, express a relation of reason, although Thomas is vaguer

\footnotetext{
13 The whole issue is finely discussed in Pini (2002, pp. 59ff.) For a close examination of the special case of self-knowledge in Aquinas, see Cory (2015), to which I refer for further literature.

14 See e.g. De pot., q. 7, a. 11, co (ed. Pession 1965, p. 212): “[...] relatio rationis consistit in ordine intellectuum; quod quidem dupliciter potest contingere: uno modo secundum quod iste ordo est adiventus per intellectum, et attributus ei quod relative dicitur; et huiusmodi sunt relationes quae attribuuntur ab intellectu rebus intellectis, prout sunt intellectae, sicut relatio generis et speciei." See also $S T$ I, q. 28, a. 1, co (Leon. 4, p. 318).
}

about their relational character. In any case, what is clear is that all these relations of reason concern things insofar as they are cognized and compared either with each other or with extramental things. They are expected to be relations of reason of a different kind with respect to the cognitive relation that a thing entertains with the subject-cognizer. As anticipated, among those listed by Aristotle in Metaphysics $\mathrm{V}$, c. 15, Thomas understands the relation entailed by the act of cognition as an example of the third kind, namely as a one-sided relation. Through an act of cognition, I am put in a real relation to a thing, while the thing is only put in a relation of reason to me. As to the foundation of the cognitive relation and its converse, its one-sided nature has a precise meaning, for Thomas: while the cognitive relation I have with a thing is really founded on my act of cognition, the relation that ensues from the fact that a thing is cognized by me has no distinct real foundation in the cognized thing. ${ }^{15}$

However, independently of how one explains the sequence of cognitive acts involved in the reflexive and comparative mechanism that governs second intentionality, Thomas points out that I am not mistaken when I perform such acts of comparison. Scholars noted that there are two texts where Thomas addresses the question of the foundation of intentions, and in both texts, he emphasizes the reliability of the process of intention formation. ${ }^{16} \mathrm{He}$ offers two different motivations, although the final position is just one. As he says in the Quaestiones de potentia, when forming the intentions, I am not mistaken because I do not attribute the intentions directly to extramental things but only to cognized things as such. Nevertheless, as clarified in the Sentences Commentary (1254-1256), intentions express recurrent modes of being of the cognized things; these are mind-independent features that emerge, however, only in consequence of my mind's act of comparison. So, as he concludes both in the Sentences Commentary and in Quaestiones de potentia 1.1 , intentions must be said to be founded proximately in things cognized, but they can also be said to be founded remotely in extramental things.

\footnotetext{
15 See Exp. Met., V, lec. 17 (ed. Spiazzi 1964, nn. 1026-1027). For a typology of the relations of reason, see In I Sent., d. 26, q. 2, a. 1, co (ed. Mandonnet 1929, pp. 630-631); and ST I, q. 13, a. 7, co (Leon. 4 , pp. 152-153). On the relation that a thing bears to the mind as a relation of reason, see In I Sent., d. 20, q. 1, a. 1, co (ed. Mandonnet 1929 , p. 505); d. 30, q. 1, a. 3, ad 3 (ed. Mandonnet 1929, pp. 708709); De pot., q. 7, a. 11, co (ed. Pession 1965, p. 212). On Aquinas's account of this kind of relation, see especially Haldane (1996). For more on Aquinas's theory of relation, see Krempel (1952); Schmidt (1966, pp. 130-174); and Henninger (1989, pp. 18-39).

16 The first text is In I Sent., d. 2, q. 1, a. 3, co (ed. Mandonnet 1929, p. 67). The second text is De pot., q. 7, a. 6, co (ed. Pession 1965, p. 201). See also De pot., q. 1, a. 1, co (ed. Pession 1965, pp. 10-11). For a closer discussion of these texts, see Pini (2002, pp. 54ff.) and De Rijk (2005, pp. 120ff.)
} 
(3) The last thing we may note about Thomas is that in no place, to my knowledge, does he make a sharp distinction between the subject-cognizer and the thing-cognized sides of intentionality. It is one thing to consider intentional being as a subject's mode of cognizing and another thing is to consider it as a thing's mode of being cognized (which can be further specified in predicative terms). It would be false, however, to state that in no way does Thomas have this distinction present. There is evidence in his works that he acknowledges the plurality of senses of intentional being. Early in his career, in the Summa contra gentiles for example (1259-1265), one can find him claiming that the intellect and the cognized thing differ in this: while the property of being cognizing does not express all the essence of the former, the property of being cognized completely expresses the essence of the latter. ${ }^{17}$ Thomas is recognizing here the existence of two kinds of epistemic properties: those expressed by an epistemic verb taken grammatically in the active form (such as "being cognizing" and the like), which pertain to the subject cognizer, and those expressed by an epistemic verb taken grammatically in the passive form (such as "being cognized" and the like), which instead pertain to the cognized thing. In the Commentary on the Metaphysics, furthermore, Thomas clarifies the ontological and predicative sense of an intention such as being universal. He distinguishes the meaning of being universal, which consists in the feature of being predicable of many things, from a thing's nature, which is the bearer of the property of being universal. This distinction is a way of saying that a thing's nature can by itself be predicated of many things, but the property of being predicable of many things does not enter into its definition; it rather enters into that of being universal, which is a property that can only accidentally be predicated of a thing's nature. Thus, the property of being universal does not express what a thing essentially is, but only what a thing is when it is considered as a cognized thing and compared to other (cognized or extramental) things. ${ }^{18}$ At the end of the day, Thomas seems to acknowledge that an intentional property involves two distinct relations of reason: one epistemic, which connects a cognized thing with our mind, and one predicative, which connects a cognized thing with the extramental things or another cognized thing.

\footnotetext{
17 SCG IV, c. 11 (ed. Marc, Pera, Caramello 1961, p. 265, n. 3466). All references to $S C G$ are from Thomas Aquinas (1961). See also ST I, q. 16, a. 1, co (Leon. 4, pp. 206-207). For more on Aquinas's account of being cognized qua cognized, see Moser (2011).

${ }^{18}$ See Exp. Met., VII, lec. 13 (ed. Spiazzi 1964, n. 1570). For a clear description of the distinction between intentional properties and underlying nature, see De ente et essentia, c. 3 (Leon. 43, p. 375, 11. 120-146); also ST I, q. 85, a. 2, ad 2 (Leon. 5, p. 334). For more on this point, see Pini (2004); also Galluzzo (2004).
}

\section{Hervaeus Natalis}

Hervaeus Natalis is likely the first medieval author to write a comprehensive treatise on first and second intentionality. ${ }^{19}$ In what follows, I shall not enter into all the technicalities of Hervaeus's sophisticated theory of intentionality, which have already been discussed elsewhere. ${ }^{20}$ Rather, I shall limit myself to answering a couple of questions: what is the exact meaning of the relation of intentionality understood as the converse-relation of the relation of cognition? And how does it relate to the property of being cognized? Hervaeus's point is that the relation of intentionality is needed in order for a thing to be called an intention, first or second. If Thomas is nuanced on the nature of the relation of reason that a thing, once cognized, bears to our mind, a large part of Hervaeus's treatise is dedicated to discussing expressly this relation. This is Hervaeus's main step forward with respect to Thomas.

\subsection{Hervaeus Natalis and Intentionality as the Converse-Relation of Cognition}

Hervaeus tries to clarify what appears to be the weakest point of any correlational theory of intentionality. Suppose that I am about to cognize the man who is in front of me, say Socrates. One might think that my act of cognizing would be enough for saying that Socrates is cognized by me. Indeed, Socrates may be said to be cognized by me just when (and just because) I am cognizing him. Hervaeus instead gives an anti-reductionist response: intentionality cannot be explained as a phenomenon that involves only acts and relations concerning the orientation of my mind to the world. Viewed from the side of the cognizing mind, the phenomenon of intentionality is subjective and psychologically characterized. But viewed from the side of the cognized thing, intentionality displays some objective and universal features. In fact, if my and your act of cognizing Socrates are numerically different (as well as Socrates's being cognized by you and me), one and the same is instead what we know about Socrates (for example, that he is a man and an animal). Another reason to avoid reducing the cognized thing to the act of cognition is that they are subjects of different

\footnotetext{
19 The treatise approximately dates from 1307 to 1316 . On this, see Dijs (2012, p. 81). On Hervaeus's life and works, see de Guimarães (1938).

20 See Amerini $(2005,2009)$. On Hervaeus's theory of intentions, see also Pinborg (1974); Perler (1994); Doyle (2006); Koridze (2006); Dijs (2008, 2009, 2010, 2012); Minerd (2017); Klein (2020). I do not discuss here the question whether Hervaeus's position on intentionality changed across time. I think it did not, but there is not room for arguing for the point here. For arguments in favour of a change, instead, see Girard (2020).
} 
predications, as was said above. Thus, Hervaeus thinks that we provide a complete account of intentionality when we describe it not only from the point of view of the cognizing mind, but also from that of the thing that becomes cognized.

This passive side of the phenomenon of the mind's intentionality lies at the centre of Hervaeus's interest. Socrates is not an intention on his own account, but he becomes one when he gets actually cognized. Anyway, my occurrent act of cognition of Socrates is not enough to say that Socrates is cognized; the relation of Socrates to my mind is also required. The abstract term "intentionality" precisely conveys this intuition, as anticipated. It formally refers to the converse-relation of the relation of cognition, which Hervaeus-borrowing from Thomas-also describes as the "termination" of our mind's cognitive tendency toward the thing. The corresponding concrete term, viz., "intention", instead designates the thing that is related to the mind and that can be called an intention. The first/second intention divide concerns the intentionality understood in the concrete and indicates the order of the things that are cognized. If the thing that is related to the mind is the extramental thing, it is a first intention, while if it is the thing cognized, it is a second intention. ${ }^{21}$ Hervaeus appears correcting the inversion we noted in Thomas.

Like Thomas, Hervaeus believes that our intellective cognition begins with an extramental singular and ends at a conception. Hervaeus, however, makes a stronger claim and holds that what he calls a mental "object" (obiectum) corresponds to such a conception, giving Thomas's theory a substantive implementation. There is a difference between a conception and an object: the latter exists in our mind with a sui generis mode of existence, which Hervaeus calls "objective being", while a conception exists in the mind as in its subject of inherence, and so is endowed with what Hervaeus calls "subjective being". Socrates, for example, becomes an object when he becomes the formal correlate of an act of cognition that "terminates" at a conception, namely that of man. ${ }^{22}$ This entails that, for Hervaeus, "objective being" and "being cognized" are synonymous phrases for designating the idiosyncratic mode of being that things acquire when they are cognized. Hervaeus's primary purpose in his treatise is to prove that this mode of being is relational in character

\footnotetext{
$\overline{21}$ See DSI, d. 1, q. 1 (ed. Dijs 2012, p. 116, n. 16): "Alio modo dicitur intentio illud quod se tenet ex parte rei intellectae; et hoc modo dicitur intentio res ipsa quae intelligitur inquantum in ipsam tendit [tenditur $e d$.] intellectus sicut in quoddam cognitum per actum intelligendi. Et intentio sic dicta formaliter et in abstracto dicit terminum ipsius tendentiae sive ipsam terminationem, quae est quaedam habitudo rei intellectae ad actum intelligendi. In concreto autem et materialiter dicit illud quod intelligitur, quicquid sit illud."

22 See, e.g., DSI, d. 1, q. 1 (ed. Dijs 2012, pp. 119-120, nn. 21-23).
}

in that it logically follows the converse-relation of the relation of cognition.

How our acts of cognition affect the things to which they apply was a hot topic in Hervaeus's day. Hervaeus's position was influential and some authors, like the Franciscan Peter Auriol, strongly reacted to it. Auriol's point is that a cognized thing such as man is by itself an intention just like it is by itself a rational animal. It is so because there is no way of distinguishing the thing that is cognized from its property of being cognized. As he says, they are "indistinguishably commixed". ${ }^{23}$ Hervaeus replies that Auriol's account is misleading for it leads to thinking that man is nothing other than a mental construction and that an act of cognition is a sufficient condition to attribute the property of being cognized to man. Hervaeus is instead confident, in agreement with Thomas, that we may distinguish the thing from its being cognized, so that the converse-relation of the relation of cognition is needed.

\subsection{Intentionality and the Thing's Property of Being Cognized: A Problem of Circularity}

But how can we distinguish a thing from its being cognized? If one constructs the ontology of intentionality according to medieval theories of relation, one has to solve the problem of the foundation of the relation of intentionality. At first one might think that, just like the relation of cognition is founded on the mind's real property of cognizing (which is realized by an act of cognition), so the converse-relation of intentionality is founded on the thing's real property of being cognized. This might be said in analogy to the case of a real relation, such as filiation, which is the converse-relation of the relation of paternity and is founded on the son's property of being generated, just like paternity is founded on the father's property of generating. But if Hervaeus had thought in this way, it would have been difficult for him to avoid the circularity that ensues from saying that the relation of intentionality (viz., the relation of being cognized) is founded upon the thing's real property of being cognized. Many adversaries of Hervaeus underscore this possible shortcoming. The first is, again, Peter Auriol, but Auriol's fellow Franciscan, Gerald Odonis, also criticizes it sharply in the second extensive treatise on first and second intentions from the Middle Ages (composed some years after that of Hervaeus). ${ }^{24}$

\footnotetext{
${ }^{23}$ See, e.g., In I Sent., d. 23 (ed. De Rijk 2005, pp. 737-738, n. 116; also pp. 716-719, nn. 65-73). All references to Auriol's In Sent. are from Peter Auriol (2005). On this, see Amerini (2009) and Taieb (2018b), to which I refer for other bibliographical references.

${ }^{24}$ On Auriol's and Odonis's criticism, see De Rijk (2005) and Amerini (2009). For a reconsideration of Odonis's position see also Amerini (forthcoming).
} 
Hervaeus tries to defend the need of the converse-relation and prove that no circularity is involved, in a two-step argument. First, like Thomas, Hervaeus stresses that intentionality is a relation of reason, so it is not founded on any presupposed real property in the cognized thing. ${ }^{25}$ This does not mean, however, that intentionality has no foundation at all. If it had no foundation, it would be but a different way of describing the real relation of cognition itself. Hervaeus does not give many arguments for this point, merely noting that, as it is too much to say that intentionality is a real relation, it is too little to say that it is nothing but the real relation of cognition itself considered according to reason (secundum rationem). It is one thing to speak of a real relation considered according to reason and another thing is to speak of a relation of reason. The latter is a true, albeit nonreal, relation, while the former is just a way of considering a real relation. Accordingly, Hervaeus concludes that the sentence "intentionality is founded on the cognized thing" is true if it is understood in a broad sense, namely: intentionality is founded on a thing to which corresponds an act of cognition as the foundation of the opposite relation (i.e., the relation of cognition). ${ }^{26}$

Hervaeus should not be misunderstood here. He does not want to affirm that the act of cognition is the foundation of the relation of intentionality too, but only that this relation necessarily follows as the converse of the relation of cognition whose foundation consists in the act of cognition. This is nothing more than a plausible way of reaffirming that an act of cognition is a necessary, but not sufficient, condition for having the relation of intentionality. In brief: the act of cognition founds the relation of cognition and so permits the converse-relation of intentionality to hold and to be founded on the cognized thing, but no real property in the cognized thing needs to be presupposed as the direct foundation of this converse-relation.

A modern reader may perceive this explanation as tortuous and heavily indebted to the medieval theories of relation. This was the perception that some medievals too had. Peter Auriol, once again, was not convinced by Hervaeus's first step. As noted above, Peter sees no logical absurdity in assuming that a one-sided relation be without a converserelation. In the case of cognition, it is enough to say that the thing's passive property of being cognized is caused directly by our mind, through its acts of cognition. Auriol puts particular emphasis on the logical priority of the property of being cognized over the relation of intentionality (if any): a

\footnotetext{
${ }^{25}$ See $D S I$, d. 1, q. 2 (ed. Dijs 2012, p. 121, n. 26): “[...] habitudo praedicta est vere ens rationis. [...] Nam secundum omnes habitudo rei intellectae ad intellectum est relatio rationis tantum." For a detailed illustration of this point, see DSI, q. 4, a. 1 (ed. Doyle 2008, pp. 463-464).

${ }^{26}$ See the text below, note 35 .
}

thing is in relation with the mind because it is cognized and not vice versa. ${ }^{27}$

Hervaeus replies that the relation of intentionality is instead needed and logically precedes the property of being cognized. His fundamental reason for this point invokes the universal validity of Aristotle's categorial model. Strictly speaking, categories apply to the sphere of real being (the domain of the mental is beyond the categories), but, broadly speaking, they also apply to the sphere of beings of reason. Things in the mind, too, need to be described in categorial terms to a certain degree. What I mean is that a predicative requirement seems to be what essentially compels Hervaeus to admit the converse-relation. If being cognized is accounted for (as it must be) as a property that follows from a relation (in the case, that of cognition), then it presupposes a converse-relation, just like being a son presupposes the relation of filiation on which it depends and by which a man can be denominated a son. ${ }^{28}$ And like being a son cannot be founded on the father's property of generating, so being cognized cannot be founded on the mind's property of cognizing. ${ }^{29}$

Hervaeus himself is aware that his position could risk being circular, ${ }^{30}$ and in order to avoid this complication, he takes a second step, which consists in clarifying the sense in which intentionality can be said to be founded on the cognized thing. Here Hervaeus seems to echo what Thomas says in his Sentences Commentary: the relation of intentionality is proximately founded on the cognized thing and remotely on the extramental thing. Hervaeus paraphrases this twofold foundation as actual vs. aptitudinal foundation. "A1 "Actual foundation" means that intentionality can be actually founded on a thing only after that thing has been cognized. But since any thing has an aptitude to be cognized which is intrinsic to its nature and not dependent on our mind, intentionality can also be said to be aptitudinally founded on the thing itself. This is a way of saying that a thing has by itself the possibility of entering into a relation of intentionality with our mind, although a thing actually develops this relation only in consequence of an act of cognition. The thing's natural aptitude to be cognized by our mind pertains to a thing by itself; this explains why Hervaeus takes the thing itself as the remote foundation of intentionality. But when

\footnotetext{
${ }^{27}$ See In I Sent., d. 23 (ed. De Rijk 2005, p. 717 ff., n. 70 ff.).

${ }^{28}$ See DSI, d. 2, q. 2 (ed. Dijs 2012, pp. 186-187, nn. 56-57); also d. 1, q. 1 (ed. Dijs 2012, p. 118, nn. 19-20).

${ }^{29}$ See DSI, d. 2, q. 3 (ed. Dijs 2012, p. 195, nn. 76-77). For more on Hervaeus's account of relation, see Dewender (2009), to which I refer for other bibliographical references.

${ }^{30}$ See e.g. DSI, d. 1, q. 2 (ed. Dijs 2012, p. 139, nn. 76-77). For further discussion of this and other shortcomings, see Girard (2020, pp. 360ff.)

${ }^{31}$ See DSI, q. 3, a. 1 (ed. Doyle 2008, pp. 420-422).
} 
I actually cognize a thing, the thing's natural aptitude to be cognized is actualized and so the thing becomes actually related to my mind. When this case obtains, the relation of intentionality can then be said to be founded actually on the cognized thing; this is the reason why the cognized thing may be taken as the proximate foundation of intentionality. ${ }^{32}$

The fact that things have an intrinsic and natural aptitude to be related to our mind permits considering intentionality also from the point of view of things being cognized and not just from that of our mind that cognizes things. We have seen that Hervaeus understands "actual foundation" in a broad sense, namely as meaning that intentionality is founded on a thing to which corresponds an act of cognition as the foundation of the opposite relation. Circularity would arise only in one case: if someone stated that intentionality is founded on the thing taken precisely as cognized or even on the property of being cognized itself. But if one understands the foundation of intentionality on the cognized thing in the sense that (i) intentionality is founded on the thing for which (ii) it is only accidentally the case to be cognized, then no circularity arises. ${ }^{33}$ Hervaeus thinks that Peter Auriol's criticism concerning circularity precisely follows from a misunderstanding of this point. He confounded the thing as actually conjoined to the property of being cognized with the same thing as aptitudinally disposed to be conjoined to that property. Hervaeus tries to prevent this confusion, and consequently the alleged circularity of his theory of intentionality, by making clearer the two senses in which a thing can be said to be conjoined to the property of being cognized: in one sense, a thing can be said to be "composed of this" property (compositum ex hiis), in another sense, it can be said to be "composed with this" property (compositum huic). ${ }^{34}$ Such a distinction entails that a cognized thing can be described either as the actual compound of the thing itself plus the property of being cognized or just as a thing that is accidentally conjoined with such a property. ${ }^{35}$ Splitting the

\footnotetext{
32 See DSI, q. 3, a. 1 (ed. Doyle 2008, p. 422): "est impossibile quod praedicta intentionalitas quae est relatio rei intellectae ad intellectum actu intelligentem fundetur super aliquam rem nisi sit actu intellectum obiective. Est tamen aptitudine extra quia potest esse non existente actu intelligentis." For different interpretations of this text, see Taieb (2015) and Girard (2020, pp. 363-366).

33 See DSI, q. 3, a. 1 (ed. Doyle 2008, p. 420).

34 See DSI, q. 3, a. 1 (ed. Doyle 2008, p. 418). For a similar distinction in Thomas, see Exp. Met., VII, lec. 13 (ed. Spiazzi 1964, n. 1570). For further discussion of this distinction in Hervaeus, see Amerini (2005, pp. 147 ff.); Amerini (2009); and Girard (2020, pp. 362-363).

35 See DSI, q. 4, a. 3 (ed. Doyle 2008, p. 494): "Quando ergo quaeritur utrum esse intellectum vel esse obiective in intellectu, quod est primum inter secundas intentiones, fundetur super rem ut est intellecta aut super rem absolute, dicendum est quod non super rem absolute, excluso actu intelligendi, immo oportet includere actum intelligendi ut fundamentum oppositae relationis. Et quando dicitur quod si fundatur super rem ut intellectam, cum res ut intellecta
}

thing from its property of being cognized permits Hervaeus to justify the necessity of the relation of intentionality and to exclude any short circuit of it via the property of being cognized.

Hervaeus concludes his examination of this relation with a final notice. Intentionality is a fundamental presupposition for all other second-intention properties, although it does not enter into the account of any of them. As he says, it is one thing to hold that intentionality is co-existing and it is quite another thing to hold that it is co-cognized when second intentions are formed. Intentionality holds in the case of whatever act of cognition, whether of first or of second intentionality. To this relation the various acts of second intentionality simply add two other kinds of relations of reason: as Thomas taught, those resulting from the comparison of cognized things with each other and those arising from the comparison of cognized and extramental things. ${ }^{36}$

\section{Conclusion}

Thomas Aquinas and Hervaeus Natalis defend a form of epistemological realism in which the cognized thing is distinguished from its property of being cognized. The hallmark of their position is that being intentional expresses a relational property: both from the side of the cognizing mind and from that of the cognized thing. Hervaeus in particular explains that intentionality expresses an idiosyncratic kind of relation of reason, namely the passive relation of being cognized that a thing bears to our mind when we are actively turned to it. This relational understanding of intentionality and the duplication of the cognitive relationships is likely the main difference with contemporary usage. While first intentionality expresses a form of direct cognition, second intentionality expresses

Footnote 35 (continued)

includit esse intellectum, tunc sequitur quod esse intellectum fundatur super seipsum, scilicet super esse intellectum quod est ipsummet, dicendum quod non sequitur. Quod quando dicitur 'ut intellecta', li 'ut intellecta' potest accipi vel prout res denominatur ab ipso actu intelligendi et tunc est sensus: res ut intellecta, id est, res ut sibi correspondet actus intelligendi; vel potest accipi prout res denominatur $\mathrm{ab}$ ipsa habitudine rationis quam habet ad actum intelligendi et tunc est sensus: res ut intellecta, id est, res ut habet habitudinem ad actum intelligendi. Quare dico quod ista habitudo, scilicet esse intellectum sive esse obiective in intellectu, fundatur super rem ut est intellecta primo modo, id est super rem ut ei correspondet actus intelligendi ut fundamentum oppositae relationis. Non autem secundo modo, scilicet super rem intellectam vel super rem ut habet habitudinem ad actum intelligendi, quia tunc illa habitudo praedicta fundaretur super seipsam." (Punctuation slightly modified.)

36 See DSI, d. 2, q. 6 (ed. Dijs 2012, p. 231, n. 162); also DSI, d. 1, q. 2 (ed. Dijs 2012, pp. 132-133, nn. 58-59) and q. 3, a. 2 (ed. Doyle 2008, p. 431) 
a form of reflexivity. But formally speaking, it does not differ from first intentionality, for both presuppose a cognitive converse-relation that ensues from the act of cognition and results into the property of being cognized. But in the case of second intentionality, reflexivity takes the form of a composition of two kinds of cognitive acts: one of consideration of the things that have been cognized and one of comparison of such things with other cognized things or with extramental things. But there are also some fundamental second intentions that result from comparing things directly with the mind itself, like being cognized and being an intention.

This kind of comparison, not explained in detail by Thomas, is at the centre of Hervaeus's account. If, on the one hand, Hervaeus's theory resolves problems present in Thomas's account, on the other hand, it introduces new ones. I discussed here one of them, namely the possible circularity of the relation of intentionality with the thing's property of being cognized. However intricate Thomas's and Hervaeus's explanations may be considered, their theoretical goal is clear: to distinguish the side of the subject-cognizer from that of the thing-cognized and give a metaphysical reason for accounting for the predicative implications of the phenomenon of intentionality.

To a modern reader, their account of intentionality may appear heavily internalist. We must however be cautious with this impression, because both Thomas and Hervaeus construct their account of intentionality with the purpose of defending the real import of our intellective knowledge. In fact, they make a realist and anti-reductionist claim about the nature of the cognized thing. What is in relation with our mind is an extramental thing's nature. Our acts of cognition do not modify really the nature of a thing, but simply put it in relation with the mind. Hervaeus, in particular, devotes a long question (DSI, q. 4 , a. 1) to explaining that a cognized thing can be assessed as partly internal and partly external to the mind. Second intentions refer to things inside the mind to the extent to which they refer to things as cognized. But second intentions also refer to things outside the mind to the extent to which the cognized things do not exist subjectively in the mind. This broadens the domain of what is epistemologically real: not only real extramental things, but also negations, privations and figments are first intentions; in short, anything that, albeit being in relation to the mind, does not include in its definition such a relation to the mind. By contrast, in the definition of every second intention a reference to the mind is included: all second intentions indeed refer to predication, which is a mental operation. At the end of the day, being objectively in the intellect indicates nothing other than a relational being. With Hervaeus's vocabulary, when a thing "terminates" an act of cognition, it acquires the status of object and becomes the subject of the intentionality relation. For these reasons, Thomas and Hervaeus hold that the thing cognized remains one and common in front of numerically different cognitive acts and relations.

Acknowledgements I wish to express here my sincere gratitude to the anonymous referees and the editorial board of the review for their useful comments and suggestions. Special thanks to William Duba for revising the English of the paper. Unquestionably, the responsibility of any mistake or misunderstanding is entirely mine.

Funding Open access funding provided by Università degli Studi di Parma within the CRUI-CARE Agreement.

Open Access This article is licensed under a Creative Commons Attribution 4.0 International License, which permits use, sharing, adaptation, distribution and reproduction in any medium or format, as long as you give appropriate credit to the original author(s) and the source, provide a link to the Creative Commons licence, and indicate if changes were made. The images or other third party material in this article are included in the article's Creative Commons licence, unless indicated otherwise in a credit line to the material. If material is not included in the article's Creative Commons licence and your intended use is not permitted by statutory regulation or exceeds the permitted use, you will need to obtain permission directly from the copyright holder. To view a copy of this licence, visit http://creativecommons.org/licenses/by/4.0/.

\section{References}

Amerini F (2005) La logica di Francesco da Prato. Sismel/Edizioni del Galluzzo, Firenze

Amerini F (2009) Realism and intentionality: Hervaeus Natalis, Peter Auriol, and William Ockham in discussion. In: Brown S, Dewender T, Kobusch T (eds) Philosophical debates at the University of Paris in the first quarter of the fourteenth century. Brill, Leiden, pp 239-260

Amerini F (2013) Tommaso d'Aquino e l'intenzionalità. Ets, Pisa

Amerini F (2017) Hervaeus Natalis on universals. In: Amerini F, Cesalli L (eds) Universals in the fourteenth century. Edizioni della Normale, Pisa, pp 109-137

Amerini F (forthcoming) Hervaeus Natalis (and his heirs) vs. Scotus (and the scotists) on mental being. Brepols, Turnhout. https:// www.arabische-philosophie.uni-freiburg.de/arabphil/owtw

Black DL (1999) Mental existence in Thomas Aquinas and Avicenna. Mediaev Stud 61:45-79

Brower JE, Brower-Toland S (2008) Aquinas on mental representation: concepts and intentionality. Philos Rev 117(2):193-243

Cesalli L (2010) Objects and relations in correlational theories of intentionality. The case of Franciscus de Mayronis. Quaestio 10:267-284

Cory T (2015) Aquinas on human self-knowledge. Cambridge University Press, Cambridge

Cory T (2020) Aquinas's intelligible species as formal constituents. Documenti e Studi Sulla Tradizione Filosofica Medievale 31:261-309

De Guimarães A (1938) Hervé Noël (†1323): etude biographiques. Arch Fratrum Praedic 8:5-81

De Rijk LM (2005) A study on the medieval intentionality debate up to ca. 1350. In: De Rijk LM (ed) Giraldus Odonis O.F.M. Opera philosophica, vol 2: De intentionibus. Brill, Leiden, pp 19-372

Dewender T (2009) Der ontologische Status der Relationen nach Durandus von St.-Pourçain, Hervaeus Natalis und Petrus Aureoli. In: Brown S, Dewender T, Kobusch T (eds) Philosophical debates 
at the University of Paris in the first quarter of the fourteenth century. Brill, Leiden, pp 287-308

Dijs J (2008) Hervaeus Natalis' theory of intentions. In: Amerini F (ed) Dal convento alla città: filosofia e teologia in Francesco da Prato O.P. (XIV secolo). Zella Editore, Firenze, pp 179-195

Dijs J (2009) Intentions in the first quarter of the fourteenth century: Hervaeus Natalis versus Radulphus Brito. In: Brown S, Dewender T, Kobusch T (eds) Philosophical debates at the University of Paris in the first quarter of the fourteenth century. Brill, Leiden, pp 213-224

Dijs J (2010) Hervaeus Natalis on the proper subject of logic. Quaestio 10:197-205

Dijs J (2012) Introduction. In: Dijs J (ed) Hervaeus Natalis: De secundis intentionibus. Distinctiones I \& II. Critical edition with introduction and indices. Dissertation, University of Leiden, pp 3-103

Doyle JP (2006) Hervaeus Natalis, O.P., (d. 1323) on intentionality: its direction, context, and some aftermath. Mod Schoolman $83: 85-124$

Galluzzo G (2004) Aquinas on common nature and universals. RTPM 71(1):131-171

Galluzzo G (2010) Aquinas on mental being. Quaestio 10:83-97

Girard C (2020) The realm of entia rationis and its boundaries: Hervaeus Natalis on objective being. RTPM 87(2):349-369

Haldane JJ (1996) Intentionality and one-sided relations. Ratio 9(2):95-114

Henninger MG (1989) Relations: medieval theories. Clarendon, Oxford, pp 1250-1325

Hervaeus Natalis (2008) De secundis intentionibus. In: Doyle JP (ed) A treatise of master Hervaeus Natalis (d. 1323), the doctor perspicacissimus, on second intentions, Marquette University Press, Milwaukee

Hervaeus Natalis (2012) De secundis intentionibus. In: Dijs J (ed) Hervaeus Natalis: De secundis intentionibus, distinctiones I \& II. Critical edition with introduction and indices. Dissertation, University of Leiden

Kenny A (1993) Aquinas on mind. Routledge, London

Klein M (2020) Mental gaze and presence: Hervaeus Natalis, Peter Auriol, and John Buridan on objects of cognition. RTPM 87(2):371-392

Klima G (2017) Intentionality and mental content in Aquinas, Ockham, and Buridan. In: Amerini F, Cesalli L (eds), Universals in the Fourteenth Century. Edizioni della Normale, Pisa, pp 65-87

Koridze G (2006) Intentionale Grundlegung der philosophischen Logik: Studien zur Intentionalität des Denkens bei Hervaeus Natalis im Traktat "De secundis intentionibus". Dissertation, University of Tubingen

Krempel A (1952) La doctrine de la relation chez Saint Thomas: exposé historique et systématique. Vrin, Paris

McInerny R (1998) On the divine simplicity: Disputed question of the power of god, 7. In: McInerny R (ed) Thomas Aquinas: selected writings. Penguin, Harmondsworth, pp 291-342

Minerd MK (2017) Logic and intentionality according to Hervaeus Natalis. Dissertation, The Catholic University of America, Washington DC

Moser R (2011) Thomas Aquinas, esse intentionale, and the cognitive as such. Rev Metaphys 64(4):763-788

Oesterle J (1962) Aristotle: On interpretation. Commentary by St. Thomas and Cajetan. Marquette University Press, Milwaukee
Perler D (1994) Peter Auriol vs. Hervaeus Natalis on intentionality: a text with introductory remarks. AHDLMA 61:227-262

Perler D (2002) Theorien der Intentionalität im Mittelalter. Klostermann, Frankfurt am Main

Peter Auriol (2005) Scriptum in primum librum Sententiarum, d. 27. In: de Rijk LM (ed) Giraldus Odonis O.F.M. Opera Philosophica, vol 2: De intentionibus. Brill, Leiden, pp 695-747

Pinborg J (1974) Zum Begriff der "intentio secunda": Radulphus Brito, Hervaeus Natalis und Petrus Aureoli in Diskussion. CIMAGL 13:49-59

Pini G (2002) Logic and categories in Duns Scotus. Brill, Leiden

Pini G (2004) Absoluta consideratio naturae: Tommaso d'Aquino e la dottrina avicenniana dell'essenza. Documenti e Studi Sulla Tradizione Filosofica Medievale 15:387-438

Pini G (2005) Two models of thinking: Thomas Aquinas and Duns Scotus on occurrent thoughts. In: Klima G (ed) Intentionality, cognition, and mental representation in medieval philosophy. Fordham University Press, New York, pp 81-103

Porro P (2016) Thomas Aquinas: a historical and philosophical profile. The Catholic University of America Press, Washington DC

Rowan JP (1961) Thomas Aquinas: Commentary on the Metaphysics. Regnery, Chicago

Schmidt RW (1966) The domain of logic according to Saint Thomas Aquinas. Martinus Nijhoff, The Hague

Solère JL (1989) La notion d'intentionnalité chez Thomas d'Aquin. Philosophie 24:13-36

Stump E (1998) Aquinas's account of the mechanisms of intellective cognition. Rev Inter Phil 52:287-307

Taieb H (2015) The "intellected thing" ("res intellecta") in Hervaeus Natalis. Vivarium 53(1):26-44

Taieb H (2018a) Relational intentionality: Brentano and the aristotelian tradition. Springer, Cham

Taieb H (2018b) What is cognition? Peter Auriol's account. RTPM 85(1):109-134

Thomas Aquinas (1882-) In: Commissio Leonina (ed) Opera omnia (= Leon.). Ex Typographia Polyglotta S. C. de Propaganda Fide, Rome

Thomas Aquinas (1929) In: Mandonnet P (ed) Scriptum super libros Sententiarum (Books I and II). P. Lethielleux, Paris

Thomas Aquinas (1933) In: Moos MF (ed) Scriptum super Sententiis (Book III). P. Lethielleux, Paris

Thomas Aquinas (1961) In: Marc P, Pera C, Caramello P (eds) Liber de veritate catholicae fidei contra errores infidelium seu Summa contra Gentiles, 3 vols. Marietti, Turin Rome

Thomas Aquinas (1964) In: Spiazzi RM (ed) In duodecim libros Metaphysicorum Aristotelis expositio. Marietti, Turin Rome

Thomas Aquinas (1965) In: Pession PM (ed) Quaestiones disputatae, vol II: Quaestiones disputatae de potentia. Marietti, Turin Rome, pp 1-276

Publisher's Note Springer Nature remains neutral with regard to jurisdictional claims in published maps and institutional affiliations. 